\title{
The Local Islamic Associations and the Party-State
}

Consanguinity and opportunities

\section{Jérôme Doyon}

Translator. Will Thornely

\section{CpenEdition}

\section{Journals}

\section{Electronic version}

URL: http://journals.openedition.org/chinaperspectives/6586

DOI: 10.4000/chinaperspectives.6586

ISSN: 1996-4617

\section{Publisher}

Centre d'étude français sur la Chine contemporaine

\section{Printed version}

Date of publication: 25 November 2014

Number of pages: $37-44$

ISSN: 2070-3449

\section{Electronic reference}

Jérôme Doyon, «The Local Islamic Associations and the Party-State », China Perspectives [Online]

2014/4 | 2014, Online since 01 January 2017, connection on 28 October 2019. URL : http://

journals.openedition.org/chinaperspectives/6586 ; DOI : 10.4000/chinaperspectives.6586 


\title{
The Local Islamic Associations and
}

\section{the Party-State}

\author{
Consanguinity and opportunities
}

ABSTRACT: In order to get to the heart of interactions between the state and Muslim communities and to understand local variants in the religious field, this article will focus on the role played by the Nanjing Islamic Association. This work breaks with top-down approaches, which concentrate on religions from the point of view of the central state, as well as with studies centred on the communities themselves, which overlook links with the state. Shedding light on the historical legacies of the Association and the networks of people comprising it shows that the link between the Party-state and religious communities is not a straightforward relationship of control and repression. It involves complex negotiations that have allowed a depoliticised form of Islam to develop in coastal China.

\section{KEYWORDS: Islam, religious management, Nanjing, nationalities, United Front, Party-state.}

In order to tackle the question of whether Islam can grow in the shadow of the Chinese Communist Party, with its legacy of religious repression and its fear of infiltration by globalised religious forces, we will look at concrete interactions between the state and religion in the People's Republic of China. This work breaks with studies of religions in China from the point of view of the central state and its regulations. The aim of such studies, which are based on official documents, is to produce an appraisal of official religious policy. (1) However, they fail to grasp the complexity of local situations. Moreover, the tendency of such a top-down approach is to present the relationship between the state and religious communities as being based purely on management and repression. On the other hand, a number of other research projects focus on the religious communities themselves, highlighting their values, the relationships that structure such communities, and the development of cultural practices. Studies of this kind, focused as they are on the communities, contribute vast amounts of information and provide the basis for understanding their internal workings. (2) However, emphasising the communities as such tends to implicitly separate the religious field from the workings of the state.

We wish to explore the heart of negotiations between the state and Muslim communities to define a space for worship. In order to do so, we will concentrate on the players who are central to these interactions: the official Islamic associations.

Ever since the early years of the People's Republic of China, the religious policy of the Chinese Communist Party (CCP) has been based on patriotic religious associations in charge of the five authorised religions: Buddhism, Taoism, Islam, Catholicism, and Protestantism. ${ }^{(3)}$ Little research has been carried out into these ambivalent associations, which were created by the Party-state both to represent the interests of believers and to apply religious policies. The interaction between these two roles, which at first glance seem contradictory, needs to be clarified.
In the case of Islam, the grouping together of Chinese Muslims into ten national minorities (shaoshu minzu), (4) giving them an official status in relation to the Han majority, further complicates the situation. In addition to the Party-state's approach to the communities in terms of religious policies is its so-called "national minorities work" (minzu gongzuo). In the case of

1. In particular, see: Beatrice Leung, "China's religious freedom policy: The art of managing religious activity," China Quarterly, No. 184, December 2005, pp. 894-913; Kim-Kwong Chan and Eric R. Carlson, Religious Freedom in China: Policy, Administration, and Regulation: A Research Handbook, Santa Barbara, CA, Institute for the Study of American Religion, Hong Kong Institute for Culture, Commerce and Religion, 2005; Fuk-Tsang Ying, "New wine in old wineskins: An appraisal of religious legislation in China and the regulations on religious affairs of 2005," Religion, State \& Society, Vol. 34, No. 4, December 2006, pp. 347-373; Jason Kindopp and Carol Lee Hamrin, God and Caesar in China: Policy implications of church-state tension, Washington, DC, Brookings Institution Press, 2004; Karl-Fritz Daiber, "Les Associations des cinq religions officiellement reconnues en République populaire de Chine" (The associations of the five religions officially recognised in the People's Republic of China), Social Compass, 2004, Vol. 51, No. 2, pp. 255-271; Pitman B. Potter, "Belief in control: Regulation of religion in China," China Quarterly, No. 174, June 2003, pp. 317-337.

2. In the case of Islam, in particular, see: Elisabeth Allès, Musulmans de Chine: une anthropologie des Hui du Henan (Muslims in China: An anthropology of the Hui of Henan), Paris, Éditions de l'École des Hautes Études en Sciences Sociales, 2000; Maris Boyd Gillette, Between Mecca and Beijing: Modernization and consumption among urban Chinese Muslims, Stanford, Stanford University Press, 2000; Dru C. Gladney, Dislocating China: Muslims, Minorities, and Other Subaltern Subjects, University of Chicago Press, 2004; Jonathan N. Lipman, Familiar strangers: A History of Muslims in Northwest China, University of Washington Press, 1997.

3. The role of these associations was restated in 1982 by the so-called "Document 19." See "Guanyu woguo shehuizhuyi shiqi zongjiao wenti de jiben guandian he jiben zhengce (wenjian No. 19)" (The basic viewpoint and policy concerning the religious question during our country's socialist period [Document 19]). For a complete version of the text in English, see the appendices of the work of Donald E. Macinnis (Religion in China Today: Policy and Practice, Maryknoll, N.Y., Orbis Books, 1989).

4. Just two of these groups, the Hui and the Uyghurs, together represent $90 \%$ of Chinese Muslims. Most of the Uyghurs live in Xinjiang, in northwest China and account for the largest Turkic and Turko-Mongol speaking population in the region. The term Hui refers to a population that is harder to define, being Chinese-speaking and scattered throughout China (although particularly well represented in Ningxia and Gansu, in northwest China) and, according to some specialists in the field, differing from the Han population only in terms of the practice of Islam; see Elisabeth Allès, "Confucius, Allah et Mao. L'islam en Chine," (Confucius, Allah and Mao: Islam in China), in Andrée Feillard, L'islam en Asie, du Caucase à la Chine (Islam in Asia, from the Caucasus to China), Les études de la documentation française, Paris, 2001, pp. 207-239. 
the Muslim minorities, this "work" mainly affects their eating, funerary, and cultural habits. Apart from their religious value, these three subjects are dealt with as customs of the groups. ${ }^{(5)}$ The two facets of Islam in China, the religious and the "ethnic," are inextricably linked from the perspective of the state and Islamic associations. This duality sets Islam apart from the other religions in China and results in different political treatment. As we will see, this can sometimes assist access to state subsidies, but can also legitimise the intervention of the state into the affairs of the Muslim community.

Few studies have been carried out to illuminate the local implementation of religious policies, which provide the stage for power struggles that vary from area to area and religion to religion. As demonstrated by Yoshiko Ashiwa and David L. Wank in their study on Nanputuo Temple in Xiamen, ${ }^{(6)}$ or indeed David Palmer in his work on the qigong movement, ${ }^{(7)}$ the networks of players need to be brought to light in order to truly understand the interactions between the state, the Party, and the religious organisations. What, then, are the factors that help explain local variations in how Islam, in particular, is managed? We will endeavour to answer this question by focusing on the Nanjing Islamic Association (NIA), ${ }^{(8)}$ a local organisation of the national association responsible for Islam, the Islamic Association of China (IAC). ${ }^{(9)}$

The city of Nanjing, capital of the jiangsu Province, is an interesting case. It does not have the exceptional character of Beijing where, as the centre of power, ideological orthodoxy appears to play an important role in the implementation of religious policy. Moreover, Nanjing is far more accessible than other regions where Muslims are more numerous, such as Xinjiang, especially since the separatist question does not colour the authorities' approach to the religious community.

Less than $2 \%$ of the population of Nanjing are officially registered Muslims. ${ }^{(10)}$ Despite the small size of their group in numerical terms, the history of Nanjing's Muslims is very particular. The Muslim population of Nanjing is especially urbanised and integrated into the running of the city. As the imperial capital at the start of the Ming dynasty (between 1368 and 1421), Nanjing attracted Muslim populations from the shopkeeper and educated classes. ${ }^{(11)}$ In the Jiangnan region, which extends roughly between Shanghai, Hangzhou, and Nanjing, an Islamic educational network that would have a very strong influence in the history of Chinese Islam grew at the end of the Ming dynasty and under the Qing. This network was responsible for disseminating Islamic knowledge of Confucian inspiration in Chinese in the form of the Han kitab compilation, (12) the first corpus of Islamic texts written in Chinese. The Muslim intellectuals behind the Han kitab portrayed their distinctive religious and cultural characteristics as being not only inoffensive to Chinese society but also echoing Confucian values, putting to one side any political claims of Chinese Islam. ${ }^{(13)}$ This role in the history of Chinese Islam gave the city of Nanjing a symbolic position in terms of representation of the Hui community, despite its relatively small Muslim population. ${ }^{(14)}$

Since the 2000s, the ranks of this ancient Muslim community have been swelled by increasing internal migration of Muslim populations coming predominantly from the provinces in northwest China with a high proportion of Muslims, in particular Gansu. In Nanjing in 2011, between 70,000 and 80,000 Muslims held a residence permit for the city, and there were a further estimated 30,000 to 53,000 migrants, depending on the source. (15) The migrants, who are generally more devout than local Muslims, fill Nanjing's mosques. ${ }^{(16)}$ This growth in religious fervour in the eastern regions has led to a problem concerning a shortage of places of worship.
The aim of this article is to highlight the historical legacies and networks of players who influence local Islam in its relationship with the Party-state. It is based on field work carried out in Nanjing at the beginning of 2011, which allowed us to access internal documents of the Nanjing Islamic Association and the mosque management committees, as well as to conduct 25 interviews with officials of the Party-state, members of the religious orders, leaders of municipal and provincial Islamic Associations, and other members of the Muslim community, intellectuals, and shopkeepers.

\section{The historical centralisation of the management of Islam in Nanjing}

\section{A legacy of national Muslim organisations in Nanjing}

In order to understand the specific situation of Islam in Nanjing, attention needs to be turned to the legacy of the Muslim organisations that existed prior to the People's Republic of China. Current relations between mosques, religious associations, and administrations of the Party-state can be traced back to a strong tradition of centralising the management of local Islam.

Under the Republic of China, Muslim populations organised themselves into interest groups in order not to be treated as marginal or potentially dangerous groups. The Chinese state needed bodies representing the various religions with whom they could liaise in order to negotiate a boundary between the political and the religious. For this reason, one of the first Islamic associations with a national reach, the Islamic Union of the Republic of China (Zhonghua minguo huijiao lianhehui), was created in 1912 in Nanjing, which at that time was the capital. ${ }^{(17)}$ The Islamic Union was in competition with the Association for the Advancement of Islam in China (Zhongguo huijiao jujinhui), which was created in Beijing the same year. ${ }^{(18)}$ Both associations collapsed during the first years of their existence or at the time of the

5. "Chuo li tongxin gongmou fazhan yushi jujin zaichuang huihuang: ji nanjingshi chengshi minzu gongzuo" (Working together and with strength to recreate the exquisite - national minorities work in the city of Nanjing), Nanjing minzuzongjiao, 2009, pp. 8-11.

6. See Yoshiko Ashiwa and David L. Wank, "The politics of a reviving Buddhist Temple: State, Association, and Religion in Southeast China," The Journal of Asian Studies, Vol. 65, No. 2, 2006, pp. 337359 .

7. David A. Palmer, Qigong Fever: Body, Science, and Utopia in China, Columbia University Press, 2007.

8. "Nanjingshi yisilanjiao xiehui" in Chinese.

9. "Zhongguo yisilanjiao xiehui" in Chinese.

10. Records Compilation Committee of the city of Nanjing, Nanjing minzu zongjiao zhi (Records of religions and national minorities of Nanjing), Nanjing, Nanjing chubanshe, 2009.

11. Mi Shoujiang, "Zhongguo yisilanjiao dushihua de guocheng jiqi fazhan qushi" (Trends in the process of urbanisation of Chinese Islam), Shijie zongjiao wenhua, 2010, pp. 56-60.

12. The title combines the character Han, referring to the Chinese world, and the Arabic word for "book" (kitab).

13. James D. Frankel, "'Apoliticization': One Facet of Chinese Islam," Journal of Muslim Minority Affairs, Vol. 28, No. 3, 2008, pp. 421- 434.

14. Zvi Ben-Dor Benite, The Dao Of Muhammad:A Cultural History Of Muslims In Late Imperial China, Harvard, Harvard University Press, 2005.

15. Bai Youtao, "Jiji bangzhu liudong musilin shiying chengshi shehui" (Actively helping Muslim migrants to adapt to urban society), Nanjing musilin, February 2011, pp. 49-50; Mi Shoujiang, "Zhongguo yisilanjiao dushihua de guocheng jiqi fazhan qushi," art. cit., pp. 57-58.

16. Taking feast days as an example, in 1993, Jingjue Mosque, the main place of gathering in the city, attracted just 600 people to celebrate the start of the month of Ramadan. This number has now risen to nearly 10,000 people. See Wu Yiye, Nanjing huijiao yisilanjiao shigao (Manuscript on the history of Islam and the Hui of Nanjing), Nanjing, Nanjing yisilanjiao xiehui, 1999, p. 244.

17. Ibid., p. 215

18. Elisabeth Allès, Leïla Chérif-Chebbi and Constance-Hélène Halfon, "L'islam chinois, unité et fragmentation" (Chinese Islam, unity, and fragmentation), Archives de sciences sociales des religions, No. 115,2001 , p. 16 
Sino-Japanese War, and their brief existences did not allow them enough time to have a significant effect on how the religion was managed. In spite of this, they did leave behind a legacy based on a stance of both separation from state institutions and direct dialogue with the state. ${ }^{(19)}$

When a central government was established in 1928, a new generation of associations was born. The main national Muslim organisation was then the Friendly Association of the Hui People of China for the Salvation of the Country (Zhongguo huimin jiuguo xiehui), which was founded in 1938 in Nanjing. In 1939, it moved to Chongqing with the nationalist government, which was fleeing the Japanese advance. In 1943, it changed its name to the Chinese Muslim Society (Zhongguo huijiao xiehui zonghui) before returning to Nanjing in 1945. However, it did not have time to remodel the traditional way in which mosques were managed before it was forced to leave for Taiwan in 1949 with the government of the Republic of China, where it is still based today.

After the city was taken by the People's Liberation Army, Ma Zhuoran, an official in the municipal United Front Department ${ }^{(20)}$ and director of the Provincial National Minority Affairs Bureau, established an association responsible for organising the worship of Islam. ${ }^{(21)}$ The Preparation Committee of the Association of Hui People of Nanjing (Nanjing huimin xiehui choubei weiyuanhui) was set up, taking over the old premises and assuming the task of managing the local organisation of the Chinese Muslim Society. This provisional committee was replaced in May 1954 by the Association for the advancement of Hui culture of Nanjing (Nanjingshi huimin wenhua xiejinhui), which became the Nanjing Islamic Association (Nanjingshi yisilanjiao xiehui, NIA) on 5 April 1959, once again under the direction of Party official Ma Zhuoran. (22)

The NIA was one of the first local Islamic associations, created on the model of the Islamic Association of China (IAC). ${ }^{(23)}$ It was the first local association to be established in a coastal province, where the percentage of Muslims was very low. The network of local associations therefore grew mainly in the 1980s, and they continue to be created at the district level today. (24) This early opening of the NIA is understandable in view of the legacy of the Islamic organisations already present in the city at the time of the Republic.

\section{The centralisation of control of the mosques}

Alongside the patriotic associations, organisations for managing places of worship were also developing. In January 1950, the Management Committee of the Mosque on Taiping Street in Nanjing (Nanjing taipinglu qingzhensi guanli weiyuanhui) was created. Based on the model of the old mosque management teams that existed under the Empire, (25) the mosque managed its finances, its activities, and the distribution of scholarships for Hui schools in the city. The management committee was led by the party official $\mathrm{Ma}$ Zhuoran, unlike the old mosque management teams, which enjoyed independence from the state. Similar teams were set up in the same year for other mosques in the city.

In 1958, a reform was initiated at a national level with the aim of eliminating "feudal elements" of Chinese Islam, in particular targeting the independent system of managing the mosques. ${ }^{(26)}$ This resulted in the merging of the various management groups into one mosque management team in Nanjing (Nanjingshi qingzhensi guanlizu). (27) The number of active mosques in Nanjing also dropped dramatically at the time of this reform. Of the 32 mosques and two religious schools that had been operating, only eight mosques remained open. Management of the other premises was handed back to the municipal housing management administration (shifang guanju), (28) which was required to pay a proportion of the rent generated to the mosque management team.

The centralised administration of the mosques introduced with the mosque management team of Nanjing represented a real break with the past, because it was the first system of shared management of the mosques of Nanjing, and was strengthened by the loss of financial independence of the mosques. Unlike the situation that held sway under the Qing and during the Republic, the mosques no longer benefitted from the support of the tradesmen's guilds, which disappeared after 1949. (29) The centralisation of management of religion in the early days of the PRC prepared the ground perfectly for the very strong presence of the Nanjing Islamic Association in the administration of the mosques. From the start, however, the NIA and the management team had only a reduced level of activity because of the anti-religious movements that began in 1958. The NIA, like the administration responsible for religious affairs, ${ }^{(30)}$ stopped operating completely in 1966 with the start of the Cultural Revolution. ${ }^{(31)}$

In Nanjing, the administration responsible for religious and national minority affairs, which was to become the municipal religious and national minority affairs Bureau (minzu zongjiao shiwuju) in 1981, reopened its doors in June 1979 (32) and was followed in November of that year by the NIA,

19. On this subject, see:Vincent Cossaert, "Republican Church engineering:The national religious associations in 1912 China," in Mayfair Mei-hui Yang (ed), Chinese religiosities: Afflictions of modernity and state formation, University of California Press, 2008, pp. 209-232.

20. This is one of the departments of the CCP committee. In practice, it coordinates the action of members of the mass organisations of the CCP and non-Party organisations and is in particular responsible for links with national minorities, religious groups, and Chinese from overseas. See Jean-Pierre Cabestan, Le système politique de la Chine populaire (The political system of the People's Republic of China), Paris, PUF, 1994, p. 262; Emmanuel Jourda, Les usages postrévolutionnaires d'un canon orthodoxe: Le front uni et l'invention politique de l'après-révolution en Chine [19782008] (Post-revolutionary uses of an orthodox canon:The United Front and political invention in post-revolution China [1978-2008]), PhD thesis, École des Hautes Études en Sciences Sociales, 2012).

21. Wu Yiye, Nanjing huijiao yisilanjiao shigao, art. cit., p. 180.

22. Ibid., pp. 218-220.

23. The first of these was created in 1956 in the region with the highest Muslim population, Xinjiang, and was followed by the establishment of those in Gansu in 1957 and then Ningxia in 1959 (see Mi Shoujiang and You Jia, Islam in China, Beijing, China intercontinental press, 2004).

24. Elisabeth Allès, Leïla Chérif-Chebbi and Constance-Hélène Halfon, "'L'islam chinois, unité et fragmentation" (Chinese Islam, unity, and fragmentation), art. cit., p. 22.

25. Traditionally, management of the religion in Nanjing was based on two types of institution: mosque management teams and their mortmain (waqf), and tradesmen's guilds. The former consisted of a council of "elders" elected by the men of the district and the mosque. They looked after the mosque's activities, its finances, and the recruitment of religious officials, whereas the tradesmen's guilds consisted of shopkeepers grouped together by district and trade. They were generally linked to one mosque, where they would gather. The tradesmen's guilds therefore contributed major financial support to the mosques, as well as to religious schools. This system safeguarded the prosperity of the mosques of Nanjing despite the small proportion of Muslims in the population. See Zhang Cheng and Mi Shoujiang, "Nanjing huizu shequ de xiaoshi yu huizu wenhua chuancheng de sikao" (Reflection on the disappearance of the Hui districts and heritage in Nanjing), Huizu yanjiu, No. 4, 2006, pp. 54-59.

26. Xiong Zijian, Zhonggong zhengquanxia de zongjiao (Religions under the power of the Communist Party of China), Wenjin, Wenjin chubanshe youxian gongsi, 1998, p. 47; Vincent Coossaert and David A Palmer, The religious question in China, Chicago and London, University of Chicago Press, 2011.

27. Wu Yiye, Nanjing huijiao yisilanjiao shigao, pp. 223-224.

28. This is the branch of local government responsible for the management of public buildings.

29. Zhang Cheng and Mi Shoujiang, "Nanjing huizu shequ de xiaoshi yu huizu wenhua chuancheng de sikao," art. cit.

30. Wu Yiye, Nanjing huijiao yisilanjiao shigao, p. 200.

31. We will not cover the details of the particularly violent antireligious actions committed at this time (On this subject, in particular, see: Donald E. MacInnis, Religious policy and practice in Communist China, London, Hodder and Stoughton, 1972; and Elisabeth Allès, Musulmans de Chine, op. cit.).

32. Wu Yiye, Nanjing huijiao yisilanjiao shigao, art. cit., p. 203. 
which then found itself in a precarious position. It was required to manage the restoration of places of worship that had been destroyed or transformed into places of production during the Cultural Revolution, but had not received any income during the course of the previous decade.

The rehabilitation of the main mosques of Nanjing was made possible by the decision of the Municipal Committee of the CCP in 1980 to give the NIA the right to manage the land and buildings that had been placed under the control of the municipal housing management administration in 1958. Moreover, the association received 300,000 yuan in compensation for the rent not paid by this administration between 1966 and 1980. (33) In reality, the land that was gradually returned to the NIA only constituted around a third of the land of the old mosques and religious schools that had been handed, for management purposes, to the municipal housing management administration in 1958. The remainder was kept by the municipality to develop its infrastructure, in particular to provide space to build new roads and widen existing ones. The NIA thus obtains the vast majority of its income from rent paid on this land. It also used some of the land for its own purposes, in particular for housing the ahong ${ }^{(34)}$ or for developing businesses. In addition to inheriting control of the land and the associated income, the NIA took back centralised control of the mosques, which had been put in place in 1958. This was a different situation to that found in provinces that had a higher Muslim population density, where mosques were placed under decentralised management.

\section{The distinctive nature of minority Islam}

Although the number of local Islamic associations grew considerably in the 1980s, ${ }^{(35)}$ our interviews reveal that in many provinces they enjoyed only a limited role, essentially as mediators between the mosques and local government. Control of the mosques and their finances was decentralised at the level of the mosque management committees, which were set up systematically by the "Measures for the Democratic Management of Mosques" (qingzhensi minzhu guanli shixing banfa) published by the Islamic Association of China in 1993. This arrangement was especially common in provinces that had a high Muslim population that, by way of its donations, maintained the financial power of the management teams. ${ }^{(36)}$

The independent system of managing the mosques needs to be viewed through the prism of opposing denominations within Chinese Islam. ${ }^{(37)}$ The local Islamic associations are unable to directly manage these denominations that differ between mosques. The mosques are, moreover, too numerous in the provinces with high proportions of Muslims to be managed centrally. An article by Zhang Jingquan, Li Jinxin, and Wang Wei concerning the local Islamic associations in Xinjiang describes their limited role, showing how the associations' lack of means, and their distance from the communities, prove a major hindrance to their work. They are therefore brought back to communication channels that enable the state to enter into contact with the mosques and to obtain information on the situation of local Islam. (38)

However, our interviews also show that the arrangement that prevails in provinces with a small percentage of Muslims involves control centralised at the level of the local Islamic association. There are too few Muslims, and they are not sufficiently involved in community life to fund the mosques with their donations. This situation results in financial management being shared at the level of the Islamic association. For example, in Nanjing, the NIA not only inherited control of the land and the associated income, it also took back centralised control of the mosques, which had been put in place in 1958.

This means that the mosque management teams in Nanjing are left with almost no financial power. They are instead relegated to managing the dayto-day running of the mosques (water, electricity, cleaning), which they finance with donations from believers with the agreement of the NIA. In addition to having a say with regard to their nomination, the NIA includes the leaders of the city's mosque management committees in its permanent committee. This inclusion of their officials, coupled with their financial dependence on the NIA, makes the mosque management committees an extension of the latter.

This particular link between the NIA and the mosque management committees plays on the treatment of religious officials. As stipulated by the "Measures for the Democratic Management of Mosques," the management team of each mosque is responsible for recruiting the ahong, whereas the local Islamic association is merely required to authorise the nomination, or not. ${ }^{(39)}$ In Nanjing, however, religious officials are more closely linked to the NIA than to the mosques because the association, being in control of the religion's finances, is responsible for employing the ahong.

In regions with a high proportion of Muslims, the ahong traditionally move to a different mosque every three years. In Nanjing, since they are linked to the NIA rather than to places of worship, they change mosque very rarely, because there are too few establishments to allow a system of rotation to be properly implemented. This sedentary practice is negative from the perspective of the religious officials, because it does not allow them to regularly come upon new local situations that would force them to work on their faith and on their religious practice. Gradually, "the ahong are turning into officials," one restaurant owner from Gansu told me. Their religious practice apparently leaves so much to be desired that they need to be monitored to ensure that they follow the religious rites.

This daily monitoring of religious officials is carried out by the mosque management committees and supervised by the NIA, and involves assessing the religious practice of the ahong, the time they spend studying, services rendered to the community, and political behaviour. The ostensible aim of monitoring the work of the ahong is to improve and standardise it. In practice, it tends to foster procedural quibbling, while the spiritual dimension of their work is not a consideration. If they do not follow the practical recommendations of the NIA in terms of the daily religious rites, ahong can be excluded or dismissed. The association therefore plays off the inconsistency between the pinpoint precision of certain details of the regulations (going as far as to describe the clothing to be worn by the ahong for funeral ceremonies) against the vague nature of expressions such as "service to the pop-

33. Ibid., p. 205.

34. A term of Persian origin that refers to members of the Muslim clergy.

35. In 1995, 25 provinces and autonomous municipalities had their own associations, as did more than 420 cities and counties. See Mi Shoujiang and You Jia, Islam in China, art. cit., pp. 171-173.

36. Such a situation is described by Jonathan Lipman in the case of Gansu. See Lipman, Familiar strangers, art. cit.

37. The regions in the northwest are marked by a strong Sufi presence, which is virtually non-existent in Nanjing. This religious plurality is one of the factors that leads Lipman to refer to a "patchwork society" when describing the Hui populations of Gansu. See Jonathan N. Lipman, "Patchwork Society, Network Society: A Study of Sino-Muslim Communities," in Raphael Israeli (ed), Islam in Asia, Vol. 2, Boulder, Westview Press, 1984, pp. 245-274.

38. Zhang Jingquan, Li Jinxin, and Wang Wei, "Shilun yisilanjiao xiehui de qiaoliang niudai zuoyong" (Reflections on the role of the Islamic associations as a bridge and link), Gansu shehui kexue, No. 5,2008 , pp. 252-255.

39. See articles 27 and 28 of the 2004 "Regulation on Religious Affairs" (Zongjiao fagui guizhang zhidu huibian) of the State Affairs Council. 
ulation," which can lead to a high degree of self-censorship by the ahong.

The movement to "interpret the Quran" (Jiejing), announced in 2001 by the IAC before being implemented by the local Islamic associations, is a good example of the subtle control exerted on religious officials. It has the aim of removing poor quality sermons, in particular those that incite religious extremism, terrorism, and separatism, and is not embodied in clearly defined rules. It is more directed towards giving the ahong guidelines and imposing them gradually by practice and example. In 2002, for example, the IAC established sermon competitions, attracting ahong from all over the country and rewarding the sermons they judged to be the best. These competitions, which have been held in Jiangsu since 2002, often provide the opportunity to assemble collections of sermons that will subsequently be presented to religious officials as models. ${ }^{(40)}$

This omnipresence of administrative officials, and the very tight margin for manoeuvre left to religious officials all the way down to their daily religious practice, provides a powerful illustration of the administrative workings of Chinese religious associations, as highlighted by David Palmer in his description of them as "religious danwei." (41) The ahong are thus brought into a position of administrative and financial dependency on the NIA, in an atmosphere where the procedural completion of the rites, given the same level of importance as administrative tasks, takes precedence over the spiritual side of the job.

The centralised management method that we have mentioned and the financial dependency of the mosques and ahong with regard to the NIA ensures the preponderance of the latter. We shall now consider how the state and Party supervise these associations in order to safeguard their chain of control.

\section{The consanguinity of the association and the administration}

\section{The internal structure of Islamic associations and their administrative environment}

The NIA belongs to a network of Chinese Islamic associations connected to each other in a pyramid model with the Islamic Association of China at its apex. Officially, associations operating at a higher level "supervise" the actions of their local offshoots. ${ }^{(42)}$ This mainly involves the exchange of information and directives. The IAC produces a certain number of regulations, which are often applications of policies or administrative rules that are implemented at the provincial and then the municipal level. There are no financial links between the associations operating at different levels. The weakness of the links between Islamic associations therefore echoes the situation that has been brought to light with regard to other religions in China. ${ }^{433}$

The local associations all operate on the basis of a statute similar to that of the IAC. (44) As emphasised by the idea of "religious danwei," (45) the very structure of the religious associations is very close to that of the organisations of the CCP involving a congress of representatives ${ }^{(46)}$ that meets every five years to appoint a committee with decision-making power. Apart from appointing the committee and having the power to revise the statute of the association, the congress has a limited role. The core of decision-making power is actually delegated to the association committee, which consists of roughly half of the representatives and in turn appoints a permanent committee and a management team from within. ${ }^{(47)}$

Legally, the Islamic associations are required to register with the Civil Affairs Bureau (minzhengju) in the same way as all other social organisations, and with the Religious Affairs Bureau (RAB) in their capacity as religious organisations. The legality of their activities is then subject to monitoring by these institutions. ${ }^{(48)}$ More broadly, local religious associations are required to compromise with an array of Party and State institutions. Apart from their limited relations with the higher-level Islamic associations, these associations may need to liaise with the RAB, the United Front Department or the Political Consultative Conference. In exceptional cases, they may come into contact with other government agencies, in particular the Public Security Bureau, in order to ensure security on religious feast days or to manage illegal forms of worship, which do not fall under the RAB's jurisdiction. Although these various bodies have been identified in many research projects into the local administration of religion in the People's Republic of China, ${ }^{(49)}$ their respective remit, their weights in terms of decision-making, and the types of relationships they foster with the Islamic associations remain unknown.

The municipal RAB is the state department that has the most regular relations with the NIA. It is also the body with which the association needs to liaise most when it wishes to make a request to the local government with the aim of obtaining either authorisations or funding. Two departments within this body are responsible for the link with Islam: in addition to its First Religious Affairs Bureau (zongjiao yichu), which deals with Muslims as believers, the municipal RAB encompasses the National Minority Affairs Bureau, which approaches them as members of these minorities.

In Nanjing, the National Minority Affairs Bureau is the main body with which the NIA liaises. Islam is therefore treated more as a cultural trait of certain national minorities than as a universal religion. This means that local state authorities are able to intervene directly in the management of the

40. For further details on the growth of the movement to "interpret the Quran" at both the national level and in Nanjing, see Jérôme Doyon, Négocier la place de l'islam chinois: les associations islamiques de Nankin à l'ère des réformes (Negotiating the position of Chinese Islam: The Islamic associations of Nanjing in the reform era), Paris, Editions L'Harmattan, 2014.

41. David A. Palmer, "China's Religious Danwei: Institutionalising Religion in the People's Republic," China Perspectives, No. 2009/4, 2009, pp. 17-30.

42. "Statute of the Nanjing Islamic Association," 2010, Article 6.

43. See David A. Palmer, "China's Religious Danwei," art. cit;;Yoshiko Ashiwa and David L. Wank, "The politics of a reviving Buddhist Temple: State, Association, and Religion in Southeast China," art. cit:; Philip L. Wickeri, Seeking the Common Ground: Protestant Christianity, the Three-Self Movement, and China's United Front, Maryknoll, Orbis book, 1988.

44. See the "Statute of the Islamic Association of China" (zhongguo yisilanjiao xiehui zhangcheng), Islamic Association of China, 2006.

45. David A. Palmer, "China's Religious Danwei," art. cit.

46. Representatives are selected in two ways. Most commonly, every five years the various mosques, schools, organisations, and companies in Nanjing with a high number of Muslims (although no precise figure is stated) propose their candidates. The main criteria are as follows: belonging to the Muslim community, having an interest in the religion, age (candidates should not be more than 60 years of age), and level of study. The trend illustrates an increasingly young average age of representatives, which currently stands at around 50 years, and an increasing level of education. This first list is submitted for checking to the RAB of the city and the municipal United Front Department, which remove the names of individuals they consider unsuitable for such a position. A vote is then organised in the mosques after Friday prayers, in order to appoint the representatives from the names on this list. The second method of selection applies when a serving representative dies or is no longer able to continue in his position. As far as possible, the decision as to whom to appoint as his successor is left to him and the association committee. The remainder of the term is often transferred to a member of the family.

47. This team is made up of an honorary chairman (always a former chairman), a chairman, a team of vice-chairmen (a total of eight at the time of the research), a general secretary, one or two vice-secretaries, and councillors (former vice-chairmen of the association).

48. According to the principles of the "Administrative Regulation on the Registration of Social Organisations" (shehui tuanti dengji guanli tiaolie), State Affairs Council, 25 September 1998, and Article 6 of the "Regulation on Religious Affairs," State Affairs Council, 2004.

49. In particular, see: David A. Palmer, "China's Religious Danwei," art. cit:; Yoshiko Ashiwa and David L.Wank, "The politics of a reviving Buddhist Temple: State, Association, and Religion in Southeast China," art. cit:; Philip L. Wickeri, Seeking the common ground, op. cit. 
religion, for example by financing the construction or repair of mosques, which in theory is illegal owing to the principle of independence of religion stipulated in Article 1 of the "Regulation on Religious Affairs."

The close relations between the RAB and the Islamic associations are reinforced by the repeated presence of the same officials responsible for religious and national minority affairs at plenary sessions of the NIA and at other periodic meetings. The closeness of this link can be strengthened further if the official in question is a Hui, and their mediation role is then facilitated, as noted by Maris Boyd Gillette in her work on Xi'an. ${ }^{(50)}$ This was the case, notably, of a former vice-director of the RAB in Jiangsu, who drew attention to himself by the way in which he managed a crisis in Yangzhou. He wore a white hat to address a group of Muslims, thus indicating his affiliation with Islam, which was seen as a bold move for an official who is not supposed to display any religious affiliation.

Indeed, being on the front line for criticism and demands from members of the NIA, the powers enjoyed by the RAB appear to be very limited. Regarding the building of mosques, the municipal RAB is unable to make unilateral rulings. Article 13 of the "Regulation on Religious Affairs" stipulates that a religious association needs to obtain the agreement of the local RAB in order to establish a new place of worship. However, in practice, the process is more complex. In order to open a new mosque, the NIA needs to be given the green light by the provincial RAB as well as the municipal RAB. This is an unwritten practice, and one that does not necessarily hold true for other religions or in other provinces. For example, our interviews revealed that Buddhist temples are considered to be less sensitive and too numerous to be managed at the provincial level, so the decision-making power lies at the municipal level. Mosques are far fewer in number in the coastal regions, and the Party-state views Islam as a more sensitive question due to the dissenting dimension of Islamic fundamentalism, potential links with international terrorist networks, and separatist Uyghur organisations. ${ }^{(51)}$ While the NIA requests public funds in order to build places of worship, the RAB acts as an intermediary between the NIA and Nanjing city council, which has the last word. This mediatory position of the RAB underlines its close relationship with the NIA but also reveals its relative weakness, which sometimes forces the association to turn to other bodies that hold more sway at the local level.

The United Front Department is another important body with which the association collaborates. As an organ of the local committee of the CCP, it carries considerable political weight, which means that its intervention can, in specific cases, help resolve a situation that the RAB would be unable to manage on its own. As outlined below, although the United Front Department is very active in selecting the leaders of the association, it nevertheless cannot be considered a body with which the NIA can liaise on a regular basis in order to relay its requests. This distant position is reflected in the internal structure of the United Front Department. Since its range of actions extends far beyond religious questions, it does not have a department specifically in charge of relations with Islam. Furthermore, although its officials are sometimes present at NIA meetings, none of them are Hui, which appears to distance the administration further from the religious associations.

The municipal Political Consultative Conference appears to be another possible body with which the NIA can liaise via the representatives it sends. As a symbol of the United Front strategy, it is an assembly with a consultative role whose purpose is to represent levels of society that are not connected with the Communist Party. In theory, representatives of the
Communist Party cannot hold more than one third of the seats. The way in which representatives are selected is ambiguous, but it appears that the United Front Department at the provincial level has the last word, basing its decision on ambiguous criteria such as the suitability of the person's political behaviour or his influence in the community. Some members of the NIA, mainly the ahong, are therefore present as representatives of the religious world, making this one of the few places where an important position is given to the ahong. They are then able to make requests in their own way, even though these will be decided upon within the NIA.

These seats in the Political Consultative Conferences at various levels offer a means of conveying messages to the administration in a more organised manner and sometimes carrying more weight than when they are addressed to the RAB. Most of the problems facing Islam in Nanjing, such as the lack of places of worship or the poor level of oversight over qingzhen products, ${ }^{(52)}$ are presented at the municipal Political Consultative Conference. ${ }^{(53)}$ In exceptional cases, problems that remain unresolved can be taken up with the provincial, or indeed national, Political Consultative Conference, in particular when the question concerns legislative changes. However, the usefulness of the Political Consultative Conference is often called into question. First and foremost, it provides a platform for dialogue that, at best, makes it possible to transfer requests with more weight to the relevant local government departments, but has no decision-making power of its own.

\section{A dovetailing of staff and networks}

The Party-state has a major influence on the selection of leaders of the association. In this area, the United Front Department of the CCP has more power than the RAB. It has to make sure of leaders' allegiance to the Party, their ability to represent the community, and their administrative abilities. The Party-state seeks bodies to liaise with that are reliable and with which it can build up a relationship of trust. They must also know how to refrain from making requests that are non-negotiable or unacceptable.

Although belonging to the Hui community is one of the criteria used when choosing leaders, as stated in the NIA's statute, ${ }^{(54)}$ candidates do not have to be practicing Muslims. On the other hand, being a member of the CCP is a major advantage when it comes to becoming a leader of a local Islamic association. At the time of our research, the chairman of the NIA, as well as his first vice-chairman, ${ }^{(55)}$ were members of the Party. As we shall see, this contributed to an atmosphere of non-belief. The apparent impossibility of CCP members displaying religious affiliation should therefore be called into serious question. This is a recurring debate in the CCP, as underlined by Maclnnis in 1989, when local administrations were already aware of this situation, even though it was forbidden. For example, the United Front De-

50. Maris Boyd Gillette, Between Mecca and Beijing, art. cit., p. 112.

51. As far as Catholicism is concerned, we learned from our interviews that in Nanjing, it is also necessary to obtain approval from the national RAB in order to construct a new church, because of the tense relations between the PRC and the Vatican with regard to underground churches.

52. An expression referring to goods that are prepared according to a ritual defined by the Muslim tradition, which equates to the word hallal used in the Arab world.

53. Within the Nanjing Political Consultative Conference, a committee in charge of questions concerning minorities and religions meets every January.

54. "Statute of the Nanjing Islamic Association" (nanjingshi yisilanjiao xiehui zhangcheng), Nanjing Islamic Association, Article 24, 2010.

55. The position of first vice-chairman is important because it comes with a high level of decisionmaking power without the extensive representation activities the chairman is required to carry out. From a certain perspective, the person occupying this role holds the most power within the association. 
partment of Ningxia estimated that in the Hui villages of the province, $70 \%$ to $80 \%$ of Party officials had participated in religious activities and that $10 \%$ were believers. ${ }^{(56)}$ It appears that this phenomenon is tacitly accepted by the authorities.

The fact that NIA leaders are selected by the local administrations reinforces its connection to the latter, rather than to higher-level Islamic associations. Officials of the RAB and the United Front Department actively prepare changes to the management team with the NIA. They meet each candidate for the positions of chairman, general secretary, and vice-chairman for an assessment interview. Their first choices are always those accepted by the association committee.

This system leads to a certain consanguinity in the staff. When it was established in 1959, the NIA's chairman was Ma Zhuoran, who was also the director of the municipal RAB and vice-director of the United Front Department of Nanjing. This practice of placing an acting official at the head of the NIA ended when the latter reopened following the Cultural Revolution. In contrast to the Maoist period, the idea was to give the associations a higher level of autonomy, while maintaining their close links with the state. However, the RAB in Nanjing continued an old practice dating back to 1959 by sending some of its employees to work in the NIA. At the time of the research, four of the eight permanent staff members of the NIA, including the secretary of the association, were actually drawing a salary from the RAB.

The fact that a position as important in the day-to-day operation of the NIA as its secretary is filled by a member of the RAB ensured a certain level of compliance on the part of the association and eliminated any potential competition between the two organisations. Moreover, the practice of the administration funding the secretary of an association appears to be commonplace at the local level in China. Kenneth Foster has written of similar practices taking place in business associations in Yantai. ${ }^{(57)}$ By means of a subtle process of supporting the development of the association, the state is thus able to shape it without exerting direct and repressive control.

By studying the professions of the leaders of the NIA, it becomes clear that apart from the ahong, the organisation is dominated by academics and, above all, retired Party-state officials. For example, at the time of the research, the chairman of the NIA was Bai Meilin, former director of the Municipal Commission of Development and Reform. The first vice-chairman, meanwhile, was a former vice-director of the Nanjing Political Consultative Conference. By giving these leadership positions in the NIA to former officials, combined with the presence of RAB employees among the permanent staff members of the NIA, the state has a subtle means for spreading the principles and administrative standards that it wishes to prevail within the association.

\section{Integration of the administrative principle}

The important positions held by retired officials in the NIA create an atmosphere of non-belief. Like the permanent staff members of the RAB, these leaders are generally not considered to be close followers of the religion by members of the community, and especially by more religious migrants from the northwest. We were told a number of times that "they do not pray or observe Ramadan." They are not demanding in terms of the religious aptitude of the ahong, instead placing more emphasis on protecting social order. As far as the ahong are concerned, it is difficult for them to put pressure on the association to focus on disseminating what they consider to be the proper practice of Islam because, as employees of the NIA, they run the risk of being excluded or dismissed.

This results in the formation of a group of association leaders that share the same vision of their connection with the Party State and maintain a good relationship with it. However, the duality of the phenomenon should not be overlooked. Although the chairman of the NIA "sees religion from an official's perspective," as we were told a number of times, his links with members of the administration and his familiarity with it mean he is a particularly effective spokesperson for the association. As such, retired officials appear to play the role of intermediaries between the associations and the administration. They are "generalists" in the view of Olivier Nay and Andy Smith, producing an "ideological patchwork" that facilitates the integration of distinct institutional environments. They therefore play a role that extends beyond merely mediating between the two organisations; they also influence their values. ${ }^{(58)}$

This "consanguine alliance" is appreciated by the community insofar as its leaders can make use of their networks within the administration to help the association and local Islam grow financially, which is a key issue owing to the limited financial resources of this minority.

\section{Involving the administration in the development of local Islam}

The network of Bai Meilin, chairman of the NIA, linked with the importance of his previous position in the municipal administration, played a fundamental role in the process of NIA taking back control of the land of the old mosques in the city, which took place between 1980 and 2000. Some situations were difficult to resolve, and Bai's network of contacts made it possible to put pressure on high-level organs of the municipality. For example, certain buildings had been converted into subsidised housing for civil servants when they were in the hands of the administration. Their function had not been reviewed when the NIA took control of them in the 1980s, and they continued to be rented to civil servants for nominal sums. When this land was taken back, with the help of Bai Meilin's network of contacts, it led to a considerable increase in the NIA's income, enabling it to increase its activities, particularly regarding social welfare ${ }^{(59)}$ This is the opposite situation to the one of Islamic associations in Xinjiang, where lack of funding is depriving them of the ability to influence local Islam. ${ }^{(60)}$

The networks of the leaders of the NIA have made it possible to obtain high sums of money from the local authorities in order to rebuild the city's mosques. In his finest hour, Bai Meilin collected more than 6 million yuan in 2007 from various departments of the municipal and provincial government in order to reconstruct Jingjue Mosque, the biggest establishment of its kind in the city. The most recent project put forward by Bai Meilin involves creating a "Muslim Centre" several storeys high at the site of the old

56. See Donald E. Maclnnis, Religion in China Today, op. cit.

57. Kenneth W. Foster, "Embedded within State agencies: Business associations in Yantai," in Jonathan Unger (ed), Associations and the Chinese state: Contested spaces, Armonk, NY, M.E. Sharpe, 2008, p. 102.

58. Olivier Nay and Andy Smith (eds), Le gouvernement du compromis: Courtiers et généralistes dans l'action politique (The government of compromise: brokers and generalists in political action), Paris, Economica, 2002, p. 14.

59. For example, the NIA is in the process of having a retirement home built for Muslims, responsibility for which is expected to be handed to a private body (for further details on the social activities, see: Jérôme Doyon, Négocier la place de l'islam chinois, op. cit.).

60. Zhang Jingquan, Li Jinxin and Wang Wei, "Shilun yisilanjiao xiehui de qiaoliang niudai zuoyong," art. cit., pp. 252-253. 
mosque on Taiping Street. It will be home to various businesses that will be run either by the NIA or by third parties that will pay rent, thus increasing the NIA's income. The mosque will be on the top floor. When the project was set up, a Saudi bank proposed to finance the centre, raising the question of foreign funding in Chinese places of worship. Although some members were in favour of this Saudi contribution, the proposal was turned down by the NIA. Chinese policy is very strict with regards to the use of foreign funds to finance Islam, and the association would have needed to conduct difficult negotiations with the administration, both locally and at a national level. (61) The NIA therefore avoided a possible confrontation with the state by filtering out a "sensitive" request that it did not deem essential, and maintained its role as a reliable point of contact.

The strong links between the NIA and the local administration also enable it to negotiate with the authorities on the issue of tolerance with regard to the "grey market of religion," an expression coined by Yang Fenggang in reference to practices having uncertain legal status. ${ }^{(62)}$ The "Regulation on Religious Affairs" stipulates that in the case of Islam, the mosque is the only place where public religious activities can take place legally, and must be registered with the local RAB. However, there is a shortage of mosques in Nanjing, a problem made more acute by the high number of Muslim migrants from the northwestern parts of the country. The custom being to pray as a group on Fridays, some people invite their loved ones to pray at their homes or businesses. The authorities turn a blind eye to these "domestic prayers" provided they involve a private circle of relations. However, such groups can grow rapidly, which the administration views as a factor for instability. The possibility of legalising some of these gathering places in order to recognise them as places of worship indicated by a notice is being discussed with the municipal RAB. If this should come to pass, the NIA would designate the premises in question with the approval of the RAB, and would ensure they complied with religious regulations.

The NIA and RAB therefore have a very strong cooperative relationship that provides them with a certain degree of flexibility in their shared work. In Nanjing, this cooperation appears moreover to be facilitated by the low level of financial competition between the RAB and the NIA. The latter is guaranteed income from rent paid on the land over which it has gradually retaken control, and over which the RAB has no claim. Furthermore, contrary to the situation reported in the case of Buddhism, the city's mosques do not represent an issue in terms of tourism. ${ }^{(63)}$ Furthermore, cooperating with the AIN appears to be positive for the local RAB, because it is promoted by the central state. The city of Nanjing was thus named "Model city for the progress of unity between national minorities" (quanguo minzu tuanjie jinbu mofan chengshi) in 2009 by the State Affairs Council.

\section{Conclusion}

Ultimately, the NIA is an agency that defends the vision of local Islam that its leaders share with a part of the administration. It therefore guarantees its status as a privileged intermediary between the Party-State and Muslims by helping the material development of a depoliticised local Islam. It provides the community with a platform for discussion with the authorities, albeit one to which access is restricted, while also ensuring a certain level of social stability from the State's point of view. Finally, the link between the RAB and the NIA echoes the work carried out by David Wank on the relationship between the administration and business at a local level in China. This uncovered not an increasing degree of independence from the
State of associations that form a "civil society," but rather the development of "local coalitions" between state and civil agents. ${ }^{(64)}$ Our study is in line with the idea that shedding light on these networks helps to build an understanding of the continuous adaptation of the institutions of the Partystate and the diversity of local arrangements.

I Translated by Will Thornely.

$\checkmark$ Jérôme Doyon is a PhD candidate in Political Sciences at SciencesPo/CERI (Paris) and Columbia University (New York). He is a CEFC PhD Fellow as well.

CERI, 56 rue Jacob, 75006 Paris (Jd2988@columbia.edu).
61. In the case of Islam, foreign funding is not forbidden but is subject to a very strict control. For each project, the local RAB is required to analyse the source of the funding and then transmit the request to the IAC and to the national $R A B$. This is one of the few situations in which the national authorities are turned to in order to solve a local question. In Nanjing, the complexity of the procedure means that the request often does not even get as far as the national level. The municipal RAB generally does not have the time or the means, in particular linguistically, to investigate the source of the funding, thus preferring to turn it down directly if it does not consider the project to be of true importance, and if the NIA does not bring pressure to bear.

62. Yang Fenggang, "The red, black, and grey markets of religion in China," The Sociological Quarterly, Vol. 47, No. 1, 2006, pp. 93-122.

63. Yoshiko Ashiwa and David L. Wank show, in particular in their article on Nanputuo Temple in Xiamen, how the local Buddhist association and the RAB are constantly vying for control of the resources that the temple represents. See Yoshiko Ashiwa and David L. Wank, "The politics of a reviving Buddhist Temple: State, Association, and Religion in Southeast China," art. cit. See also ji Zhe, "Buddhism and the State:The New Relationship," China Perspectives, No. 55, 2004, pp. 2-12.

64. David L. Wank, Commodifying Communism: Business, Trust, and politics in a Chinese city, Cambridge, Cambridge University Press, 1999 